\title{
Changes in phospholipids, cholesterol and protein content of oviduct fluid of cows during the oestrous cycle
}

\author{
G. J. Killian, D. A. Chapman, J. F. Kavanaugh*, D. R. Deaver and \\ H. B. Wiggin
}

Dairy Breeding Research Center and *Department of Veterinary Science, Penn State University, University Park, PA 16802, USA

\begin{abstract}
Summary. The oviducts of 4 cows were cannulated and oviduct fluid was collected daily from the exteriorized cannulas for a total of 5 oestrous cycles. Daily serum samples were assayed for oestradiol-17 $\beta$ and progesterone to monitor the oestrous cycle. Data for each cycle were compared for oviduct fluid collected during the non-luteal phase (serum progesterone $\leqslant 1.5 \mathrm{ng} / \mathrm{ml}$ ) and the luteal phase (serum progesterone $>1.5 \mathrm{ng} / \mathrm{ml}$ ). During the non-luteal phase oviduct fluid volume was higher and the osmolality was lower than during the luteal phase. Total protein, cholesterol and phospholipid secreted daily was greater during the non-luteal phase. Cholesterol and protein concentrations were generally lower during the non-luteal phase, but phospholipid concentrations were generally higher. About $40 \%$ of the phospholipid in oviduct fluid was phosphatidylcholine and lysophosphatidylcholine, while phosphatidylinositol and lysophosphatidylinositol accounted for $20 \%$. The ratio of 1 -acyl-phospholipid to diacylphospholipid increased during the non-luteal phase. An increased cholesterol to phospholipid ratio, and a decreased cholesterol to protein ratio in oviduct fluid also were associated with the non-luteal phase. Changes in the lipid composition of oviduct fluid during the oestrous cycle may play a role in the preparation of gametes for fertilization.
\end{abstract}

Keywords: oviduct fluid; cow; phospholipid; cholesterol; protein

\section{Introduction}

The environment provided by the oviduct has long been recognized to play a significant role in promoting fertilization and early embryonic development (Elliott, 1974). Biochemical analyses of oviduct fluid collected during the oestrous cycle have been made possible by the development of surgical techniques for the placement of indwelling catheters within the ampullary end of the oviduct (Clewe \& Mastroianni, 1960; Black et al., 1963; Sutton et al., 1984). The composition of oviduct fluid recovered via cannula has been most extensively analysed for sheep and rabbits, while some work has been done with humans, monkeys, pigs, horses and cattle (see reviews by Brackett \& Mastroianni, 1974; Edwards, 1980; Zavos et al., 1982). It is apparent from these studies that oviduct fluid is biochemically complex and contains a variety of ions, sugars, proteins and lipids. Moreover, the physiological importance of oviduct fluid has been suggested by in-vitro studies of spermatozoa incubated with this fluid, which facilitates sperm capacitation (Mukherjee \& Lippes, 1972) and respiration (Black et al., 1968).

Lipid analyses of oviduct fluid have not been reported except as a way to confirm that the cannula does not damage the oviduct or upset lipid and protein balances in the fluid (Sloan \& Johnson, 1974). This is surprising since, under in-vitro conditions, cholesterol (Davis et al., 1979) and a variety of phospholipids (Fleming \& Yanagimachi, 1981) added to the incubation medium either stimulate or inhibit sperm capacitation and the acrosome reaction depending on the lipid 
added. The importance of follicular fluid lipids in these events has been suggested (Menezo et al., 1984) and is supported by findings that follicular fluid promotes capacitation in vitro (Yanagimachi, 1969).

Considering the potential importance of lipids in the preparation of spermatozoa and ova for fertilization and in early embryonic development, the present study was undertaken to assess the changes that occur in cholesterol content and phospholipid composition of oviduct fluid during the cow oestrous cycle.

\section{Materials and Methods}

\section{Oviduct fluid collection}

Four Holstein cows 3-9 years of age and displaying normal reproductive cycles were used. Laparotomies were performed under local anaesthesia and oviducts were cannulated at the ampullary end with Silastic medical-grade tubing (Dow Corning, Midland, MI, USA) having an i.d. of $1 \mathrm{~mm}$ and an o.d. of $2.2 \mathrm{~mm}$ (Kavanaugh \& Killian, 1988). Catheters were exteriorized through the flank and terminated in a $3 \mathrm{ml}$ receptacle contained within a canvas pouch which was held to the body wall with adhesive. At 24-h intervals, oviduct fluid was collected from each cow. The volume was recorded and the samples were stored in liquid nitrogen until analyses were performed.

The receptacle for oviduct fluid formed a closed system with the cannula. The device was sterile at installation and usually remained free of contamination by microorganisms during the period of fluid collection. Occasionally, when a receptacle was broken or detached, it was replaced by a new sterile device. Any oviduct fluid samples showing evidence of bacterial contamination were discarded.

\section{Endocrine assays and determination of oestrus}

Peripheral blood samples were collected every $24 \mathrm{~h}$ from a tail vein or artery. During the next $30 \mathrm{~min}$, blood samples were refrigerated, allowed to clot and centrifuged to harvest the serum. Serum was then stored at $-20^{\circ} \mathrm{C}$ until assayed.

The concentration of progesterone in plasma was determined by radioimmunoassay (RIA): $50 \mu 1$ plasma and $100 \mu \mathrm{l}$ phosphate buffer (PBS, $0.1 \%$ gelatin, $0.9 \% \mathrm{NaCl}, 0.05 \mathrm{M}-\mathrm{NaPO}_{4}, 0.01 \% \mathrm{NaN}_{3}, 0.01 \%$ heparin and $0.01 \mathrm{M}-$ $\mathrm{Na}_{2}$ EDTA) were pipetted into $12 \times 75 \mathrm{~mm}$ borosilicate tubes. After addition of $50 \mu \mathrm{l}$ rabbit anti-progesterone antiserum (Cat. No. 1127400 ; Serono Diagnostics, Norwell, MA, USA) and $50 \mu \mathrm{l}$ of ${ }^{125}$ I-labelled progesterone (Cat. No. 1127400 ; Serono Diagnostics), the tubes were incubated for $3 \mathrm{~h}$ at $22^{\circ} \mathrm{C}$. Sheep anti-rabbit serum and $1 \mathrm{ml}$ of $8 \%$ polyethylene glycol (PEG; MW-8000; Sigma Chemical Co., St Louis, MO, USA) were added, vortexed and centrifuged for $20 \mathrm{~min}$ at $1500 \mathrm{~g}$ at $4{ }^{\circ} \mathrm{C}$ to precipitate the ${ }^{125}$ I-labelled progesterone bound to the primary antiserum. The antiserum was specific for progesterone and did not cross-react $(<0.1 \%)$ with 17-hydroxyprogesterone, oestradiol, testosterone or cortisol. The average specific binding, slope, and $y$-intercept were $47.3 \%,-0.540$ and 0.878 , respectively for the progesterone RIA. The sensitivity of the assay was defined as $5 \mathrm{pg} /$ tube (the lower limit of the standard curve) and this mass displaced $6 \%$ of the ${ }^{125} \mathrm{I}$-labelled progesterone. The intra- and interassay coefficients of variation were less than $10 \%$.

The concentration of oestradiol in plasma was determined by RIA following extraction of plasma with diethyl ether. Plasma $(200 \mu \mathrm{l})$ was pipetted into $13 \times 100 \mathrm{~mm}$ polypropylene extraction tubes (Sarstedt, Inc. Princeton, NJ, USA). Diethyl ether ( $4 \mathrm{ml}$; Mallinckrodt $\$ 8084$; Thomas Scientific, Swedesboro, NJ, USA) was added, tubes were capped and shaken horizontally for $20-30 \mathrm{~min}$. The aqueous phase was frozen by immersing the tubes in liquid nitrogen for $10-15 \mathrm{sec}$. The organic phase was decanted into $12 \times 75 \mathrm{~mm}$ borosilicate tubes and the diethyl ether was evaporated in a $45^{\circ} \mathrm{C}$ water bath. Standards and $\mathrm{B}_{\mathrm{o}}$ tubes were also treated with $4 \mathrm{ml}$ diethyl ether. The ether residue was resuspended with $325 \mu$ l PBS. Then, $25 \mu$ l oestradiol antiserum (Cat. No. 47241700; Ciba Corning Diagnostics Corp., Medfield, MA, USA) were added to each tube. ${ }^{12 s}$ I-labelled oestradiol (Cat. No. 472417000; Ciba Corning Diagnostics Corp.) was reconstituted with $13 \mathrm{ml}$ PBS and $50 \mu \mathrm{l}$ were added to each tube. Tubes were vortexed and incubated for $2 \mathrm{~h}$ at $22^{\circ} \mathrm{C}$. After addition of $500 \mu \mathrm{l}$ of a solution containing an iron-conjugated second antibody (Cat. No. 472417000; Ciba Corning Diagnostics Corp.), each tube was vortexed and incubated for $10 \mathrm{~min}$. Tubes were placed in a magnetic decanting rack for 10 min to separate the free from bound ${ }^{125}$ I-labelled oestradiol. The supernatant was aspirated and the pellet counted. The average specific binding, slope and $y$-intercept were $56.3 \%,-1 \cdot 07$, and 0.74 , respectively. The recovery after extraction of $25 \mathrm{pg}$ unlabelled oestradiol was $92.1 \%$. The sensitivity of the assay was defined as $0.3 \mathrm{pg}$ (the lower limit of the standard curve) and displaced $5 \%$ of the ${ }^{125}$ I-labelled oestradiol. The incubation of extracts from 25 to $200 \mu \mathrm{l}$ of a plasma pool containing $20 \mathrm{pg}$ oestradiol $/ \mathrm{ml}$ resulted in a dose-dependent displacement of ${ }^{125} \mathrm{I}$-labelled oestradiol that was parallel to the standard curve. The intra- and interassay CVs were less than $10 \%$.

In initial studies, cows were released twice daily and observed for behavioural oestrus. However, since the increased activity and mounting which accompanied oestrus often dislodged the catheter, the practice was discontinued. Subsequently, we estimated the time of oestrus to be 4 days before the initial rise in progesterone following a period when progesterone concentrations were $\leqslant 1 \mathrm{ng} / \mathrm{ml}$. 


\section{Biochemical analyses}

The protein concentration in samples of oviduct fluid and blood serum were estimated by the method of Lowry et al. (1951) with bovine serum albumin as standard. Cholesterol concentrations were determined enzymically using a diagnostic kit (No. 351, Sigma Chemical Co., St Louis, MO. USA).

Lipids were extracted from oviduct fluid and blood serum following the method of Folch et al. (1957) using chloroform:methanol $(2: 1, \mathrm{v} / \mathrm{v})$. Based on preliminary studies we determined that a maximum phospholipid recovery of $92 \%$ was obtained when the washing step in the Folch procedure contained $0.74 \% \mathrm{KCl}$.

Phospholipids were separated by high-performance liquid chromatography. Normal phase separations were achieved with a Hibar II LiChrosorb Si60 $(4.6 \mathrm{~mm} \times 25 \mathrm{~cm})$ column (Rainin Instrument Co., Woburn, MA, USA) in series with a Supercosil LC-SI $(4.6 \mathrm{~mm} \times 5 \mathrm{~cm})$ column (Supelco, Inc. Bellefonte, PA, USA) and used with an isocratic solvent system comprised of acetonitrile/methanol/water $(65: 21: 14$, by vol.). A flow rate of $0.3 \mathrm{ml} / \mathrm{min}$ was maintained and the effluent was monitored at $207 \mathrm{~nm}$. The effluent was collected in $0.6 \mathrm{ml}$ fractions and evaporated to dryness in air. The fractions were then subjected to complete perchloric acid digestion and analysed for inorganic phosphorus (Killian \& Chapman, 1980). Unknowns were identified by comparison to elution profiles of standards for phosphatidylcholine, phosphatidylinositol, phosphatidylserine, phosphatidylethanolamine, lysophosphatidylcholine, lysophosphatidylinositol, lysophosphatidylserine, and lysophosphatidylethanolamine which were purchased from Supelco, Inc. (Bellefonte, PA, USA).

The osmolality of samples was measured on $10 \mu \mathrm{l}$ samples of oviduct fiuid by using a vapour pressure osmometer (Wescor, Inc., Logan, UT, USA).

\section{Statistical analyses}

Means for the variables were compared within each cow for non-luteal and luteal samples using a two-tailed Student's $t$ test. The confidence levels at which the two means were different are reported with each comparison.

\section{Results}

Oviduct fluid was assessed from 5 oestrous cycles. The fluid was collected from a total of 5 oviduct cannulations performed on 4 cows. The volume of fluid produced by the oviduct was typically highest around oestrus (Fig. 1). Peak fluid volumes were $1.0-2.5 \mathrm{ml} /$ day and were associated with progesterone concentrations of $\leqslant 1.5 \mathrm{ng} / \mathrm{ml}$. Cyclic changes in oestradiol also were apparent with values typically $2-4 \mathrm{pg} / \mathrm{ml}$ except around oestrus when they rose to $10-20 \mathrm{pg} / \mathrm{ml}$. Examination of the data revealed considerable variation among cows, as well as between 2 cycles for the same cow. This made it impractical to summarize the data day by day to determine whether any of the variables showed cyclic changes associated with hormone concentrations. Alternatively, data from samples of oviduct fluid for each cow were organized into two groups; those collected during the non-luteal phase of the cycle when serum progesterone values were $\leqslant 1.5 \mathrm{ng} / \mathrm{ml}$ (around oestrus), and those collected during the luteal phase when serum progesterone was $>1.5 \mathrm{ng} / \mathrm{ml}$. Using this scheme, the averages of values during the non-luteal and luteal phases of each cycle were calculated and compared for the variables by calculating the overall non-luteal and luteal phase means for all cycles (Tables 1 \& 2). Data for phospholipid composition, osmolality and concentrations of protein, cholesterol and phospholipid were also determined for blood serum samples taken during the two phases of the cycle for comparison with oviduct fluid values (Tables $1 \& 2$ ).

Concentrations of protein and cholesterol were 4-5-fold higher in blood serum than in oviduct fluid, but phospholipid concentrations and osmolality were typically higher in oviduct fluid (Table 1). Although concentrations of cholesterol in blood serum tended to increase during the non-luteal phase, cholesterol in oviduct fluid tended to increase during the luteal phase. Blood serum osmolality increased during the non-luteal relative to the luteal phase, in contrast to the decrease in oviduct fluid seen during the non-luteal phase.

Several changes in oviduct fluid associated with the oestrous cycle were observed (Table 1). The volume of oviduct fluid during the non-luteal phase was higher than during the luteal phase. Increased volume of oviduct fluid was consistently associated with decreased osmolality. Total daily protein, cholesterol and phospholipid secreted was higher during the non-luteal phase. During the non-luteal phase, concentrations of phospholipid tended to be higher but concentrations 


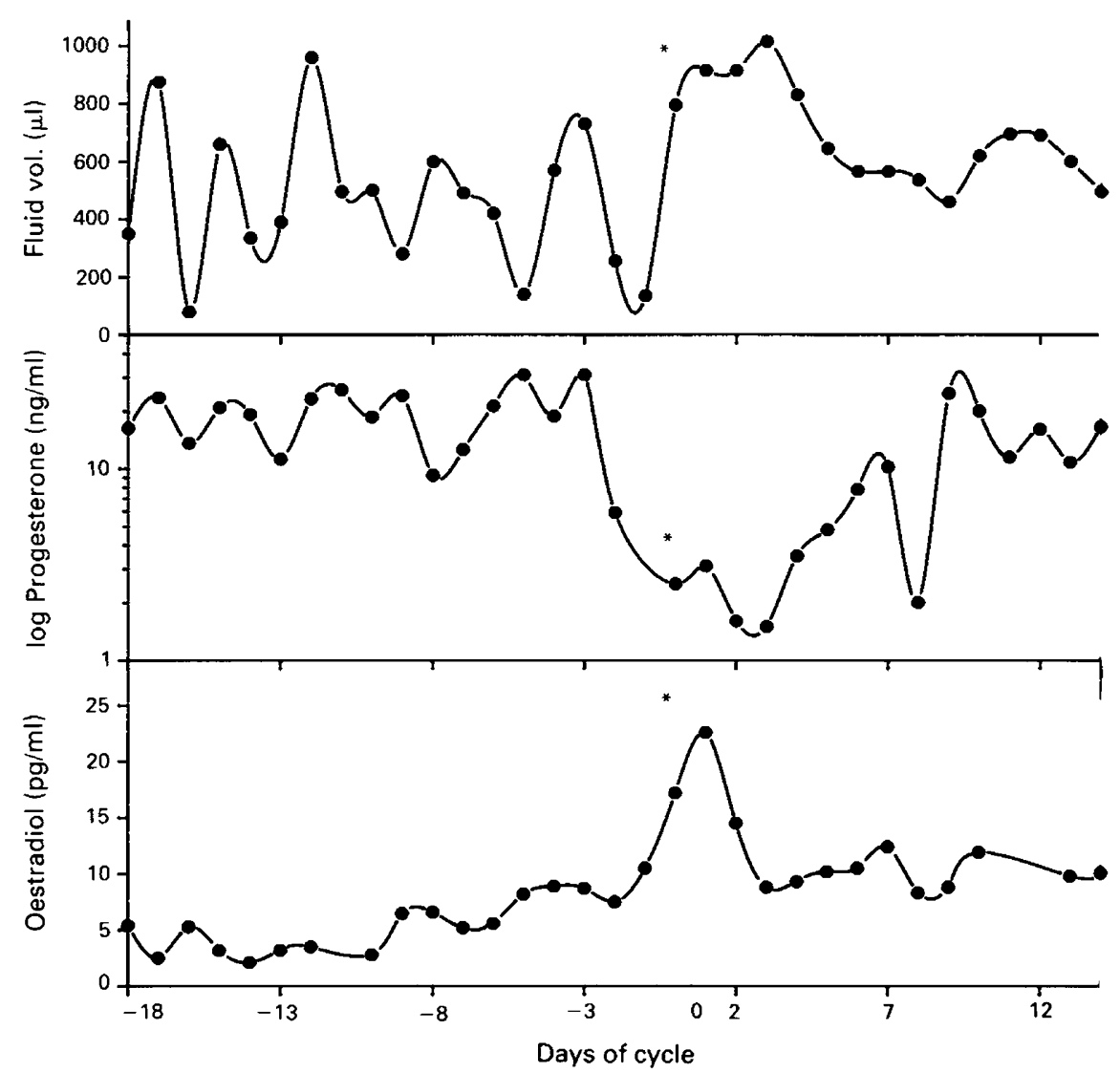

Fig. 1. Changes in oviduct fluid volume of cows during the oestrous cycle. Peak volumes of fluid occurred immediately after oestrus $\left({ }^{*}\right)$ and corresponded to low concentrations of progesterone, and a peak of oestradiol.

of cholesterol tended to be lower (Table 1). Differences in the phospholipid composition of oviduct fluid during the oestrous cycle were variable among cycles and cows. When non-luteal and luteal days of the cycle for each cow were averaged and the overall means determined, the relative distribution of phospholipid in oviduct fluid generally paralleled that of blood serum (Table 2). Lysophosphatidylcholine and phosphatidylcholine accounted for about $40 \%$ of the phospholipid present in oviduct fluid, while phosphatidylinositol and lysophosphatidylinositol comprised more than $20 \%$ of the phospholipid. Cyclic differences in phospholipid composition tended to be more evident in blood serum than in oviduct fluid. A significant increase was seen in the average percentage of phosphatidylinositol in blood serum for cows during the non-luteal phase of the oestrous cycle (Table 2). However, an increase in the ratio of 1-acyl-phospholipid to diacylphospholipid was seen in oviduct fluid samples collected on non-luteal days of the oestrous cycle. The ratios of 1-acyl to diacylphospholipid determined during the non-luteal and luteal phases for each cow were 0.76 , $0 \cdot 71 ; 1 \cdot 34,1 \cdot 16 ; 1 \cdot 64,1 \cdot 47$; and $0 \cdot 87,0 \cdot 52$, respectively.

Changes in the ratios of concentrations of cholesterol to protein and phospholipid to cholesterol or protein were also observed during the cycle (Table 3 ).

\section{Discussion}

The results of this study clearly support earlier findings that fluid production by the oviduct is affected by hormonal changes occurring during the oestrous cycle and that maximum volumes of 
Table 1. Composition of oviduct fluid and serum when serum progesterone concentrations were $\leqslant 1.5 \mathrm{ng} / \mathrm{ml}$ (non-luteal phase) and when they were $>1.5 \mathrm{ng} / \mathrm{ml}$ (luteal phase)*

\begin{tabular}{|c|c|c|c|}
\hline & \multirow{2}{*}{$\begin{array}{l}\text { Cycle } \\
\text { phase }\end{array}$} & \multicolumn{2}{|c|}{ Mean all cycles } \\
\hline & & Oviduct fluid & Blood serum \\
\hline $\begin{array}{l}\text { Volume } \\
(\mathrm{ml})\end{array}$ & $\begin{array}{l}\text { Non-luteal } \\
\text { Luteal }\end{array}$ & $\begin{array}{c}0.99 \pm 0.19 \\
0.40 \pm 0.06 \\
(0.99)\end{array}$ & \\
\hline $\begin{array}{l}\text { Osmolality } \\
\text { (mosmol/kg) }\end{array}$ & $\begin{array}{l}\text { Non-luteal } \\
\text { Luteal }\end{array}$ & $\begin{array}{l}295 \pm 9 \\
332 \pm 14 \\
(0 \cdot 87)\end{array}$ & $\begin{array}{c}276.1 \pm 1.6 \\
265.9 \pm 3.7 \\
(0.95)\end{array}$ \\
\hline $\begin{array}{l}\text { Protein } \\
(\mathrm{mg} / \mathrm{ml})\end{array}$ & $\begin{array}{l}\text { Non-luteal } \\
\text { Luteal }\end{array}$ & $\begin{array}{c}8 \cdot 5 \pm 1 \cdot 1 \\
9 \cdot 6 \pm 1 \cdot 4 \\
(0 \cdot 67)\end{array}$ & $\begin{array}{c}35 \cdot 8 \pm 2 \cdot 2 \\
35 \cdot 1 \pm 1 \cdot 3 \\
(0.61)\end{array}$ \\
\hline $\begin{array}{l}\text { Protein } \\
(\mathrm{mg} / 24 \mathrm{~h})\end{array}$ & $\begin{array}{l}\text { Non-luteal } \\
\text { Luteal }\end{array}$ & $\begin{array}{c}8 \cdot 7 \pm 2 \cdot 7 \\
3 \cdot 8 \pm 0 \cdot 6 \\
(0.99)\end{array}$ & \\
\hline $\begin{array}{l}\text { Cholesterol } \\
(\mu \mathrm{g} / \mathrm{ml})\end{array}$ & $\begin{array}{l}\text { Non-luteal } \\
\text { Luteal }\end{array}$ & $\begin{array}{c}143 \pm 19 \\
175 \pm 25 \\
(0 \cdot 76)\end{array}$ & $\begin{array}{c}903.3 \pm 30.2 \\
871.6 \pm 39.5 \\
(0.73)\end{array}$ \\
\hline $\begin{array}{l}\text { Cholesterol } \\
(\mu \mathrm{g} / 24 \mathrm{~h})\end{array}$ & $\begin{array}{l}\text { Non-luteal } \\
\text { Luteal }\end{array}$ & $\begin{array}{c}153 \pm 56 \\
70 \pm 14 \\
(0 \cdot 98)\end{array}$ & \\
\hline $\begin{array}{l}\text { Phospholipid } \\
(\mu \mathrm{mol} / \mathrm{ml})\end{array}$ & $\begin{array}{l}\text { Non-luteal } \\
\text { Luteal }\end{array}$ & $\begin{array}{c}324 \pm 289 \\
90 \pm 36 \\
(0.91)\end{array}$ & $\begin{array}{c}31 \cdot 1 \pm 20 \cdot 2 \\
20 \cdot 7 \pm 13 \cdot 7 \\
(0.65)\end{array}$ \\
\hline $\begin{array}{l}\text { Phospholipid } \\
(\mu \mathrm{mol} / 24 \mathrm{~h})\end{array}$ & $\begin{array}{l}\text { Non-luteal } \\
\text { Luteal }\end{array}$ & $\begin{array}{c}144 \pm 83 \\
95 \pm 38 \\
(0 \cdot 65)\end{array}$ & \\
\hline
\end{tabular}

*Five cycles from 4 cows are represented. Values shown are the mean ( \pm s.e.m.) of the averages for each cycle for 4-7 non-luteal samples or 11-19 luteal samples. Numbers in parentheses are the probability levels that the non-luteal and luteal means are different using a Student's two-tailed test.

fluid are produced around oestrus. Studies involving ovariectomy followed by hormone replacement with many species also have shown that the secretory activity of the oviducal epithelium is dependent on oestrogen. While our findings support this general conclusion, they also indicate that the cyclic fluctuation of fluid production is dependent on changes in circulating concentrations of progesterone. Peak oviduct fluid secretion consistently occurred with a sharp drop in progesterone and usually followed a rise in oestrogen. For those cycles in which no apparent rise in oestrogen occurred, increased oviduct fluid volume was still observed with a drop in progesterone. Progesterone appears to be antagonistic to oestrogen in the oviduct so that, when progesterone is minimal during the cycle, the maximal stimulation of oviduct secretory activity occurs in response to oestrogen. This concept is supported by early experiments, with ovariectomized rabbits (Mastroianni et al., 1961) and ewes (McDonald \& Bellve, 1969), using exogenous progesterone and oestradiol benzoate. These studies showed that the secretory activity of the oviduct was less when both progesterone and oestradiol benzoate were used than when oestradiol benzoate was used alone.

Total secretions for $24 \mathrm{~h}$ of phospholipid, cholesterol and protein in oviduct fluid were consistently higher around oestrus than at other times of the cycle. Although the concentrations of protein or cholesterol did not increase in the fluid around oestrus relative to the luteal phase, the increased total daily secretions of these substances is nevertheless consistent with increased secretory activity of the oviduct. If the increased volume of oviduct fluid were simply due to an 
Table 2. Percentage of various phospholipids in oviduct fluid and blood serum when serum progesterone concentrations were $\leqslant 1.5 \mathrm{ng} / \mathrm{ml}$ (non-luteal phase) and $>1.5 \mathrm{ng} / \mathrm{ml}$ (luteal phase)*

\begin{tabular}{lccc}
\hline & Cycle & \multicolumn{2}{c}{ Mean all cycles } \\
\cline { 3 - 4 } & phase & Oviduct fluid & Blood serum \\
\hline Phosphatidylinositol & Non-luteal & $20 \cdot 9 \pm 4 \cdot 7$ & $24 \cdot 2 \pm 1 \cdot 2$ \\
& Luteal & $22 \cdot 0 \pm 3 \cdot 3$ & $15 \cdot 3 \pm 2 \cdot 5$ \\
& & $(0 \cdot 56)$ & $(0 \cdot 99)$ \\
Phosphatidylethanolamine & Non-luteal & $4 \cdot 7 \pm 1 \cdot 1$ & $3 \cdot 8 \pm 1 \cdot 0$ \\
& Luteal & $6 \cdot 4 \pm 0 \cdot 9$ & $3 \cdot 5 \pm 1 \cdot 1$ \\
& & $(0 \cdot 81)$ & $(0 \cdot 57)$ \\
Phosphatidylserine & Non-luteal & $7 \cdot 9 \pm 1 \cdot 9$ & $7 \cdot 8 \pm 2 \cdot 4$ \\
& Luteal & $7 \cdot 7 \pm 0 \cdot 9$ & $14 \cdot 3 \pm 3 \cdot 1$ \\
Phosphatidylcholine & & $(0 \cdot 50)$ & $(0 \cdot 91)$ \\
& Non-luteal & $21 \cdot 9 \pm 4 \cdot 3$ & $10 \cdot 8 \pm 2 \cdot 1$ \\
& Luteal & $20 \cdot 2 \pm 2 \cdot 0$ & $19 \cdot 4 \pm 4 \cdot 9$ \\
Lysophosphatidylcholine & & $(0 \cdot 65)$ & $(0 \cdot 89)$ \\
& Non-luteal & $18 \cdot 2 \pm 3 \cdot 5$ & $19 \cdot 9 \pm 1 \cdot 9$ \\
& Luteal & $19 \cdot 4 \pm 2 \cdot 2$ & $19 \cdot 9 \pm 2 \cdot 9$ \\
Lysophosphatidylinositol & & $(0 \cdot 60)$ & $(0 \cdot 0)$ \\
& Non-luteal & $10 \cdot 0 \pm 4 \cdot 7$ & $15 \cdot 9 \pm 1 \cdot 4$ \\
& Luteal & $8 \cdot 3 \pm 1 \cdot 4$ & $15 \cdot 5 \pm 1 \cdot 0$ \\
Lysophosphatidylethanolamine + & & $(0 \cdot 68)$ & $(0 \cdot 64)$ \\
lysophosphatidylserine & Non-luteal & $15 \cdot 6 \pm 3 \cdot 4$ & $17 \cdot 5 \pm 2 \cdot 1$ \\
& Luteal & $14 \cdot 8 \pm 1 \cdot 7$ & $12 \cdot 5 \pm 2 \cdot 1$ \\
& & $(0 \cdot 58)$ & $(0 \cdot 86)$ \\
\hline
\end{tabular}

*Five cycles from 4 cows are represented. Values shown for oviduct fluid are the mean\pm s.e.m. for the averages of each cycle containing 3-7 non-luteal samples or 13-17 luteal samples. Values for blood serum are the mean \pm s.e.m. for the averages of each cycle of samples taken during the non-luteal and luteal phases. Numbers in parentheses are the probability levels that the non-luteal and luteal means are different using a Student's two-tailed test.

Table 3. Ratios of concentrations of cholesterol to protein and phospholipid to cholesterol or protein in oviduct fluid taken when serum progesterone concentrations were $\leqslant 1.5 \mathrm{ng} / \mathrm{ml}$ (non-luteal) and $>1.5 \mathrm{ng} / \mathrm{ml}$ (luteal)*

\begin{tabular}{lcc}
\hline Ratio & $\begin{array}{c}\text { Non- } \\
\text { luteal }\end{array}$ & Luteal \\
\hline Cholesterol:protein & $16 \cdot 8$ & $18 \cdot 2$ \\
Phospholipid:cholesterol & $2 \cdot 3$ & 0.5 \\
Phospholipid:protein & $37 \cdot 2$ & $23 \cdot 7$ \\
\hline
\end{tabular}

* Ratios were calculated from oviduct fluid data in Table 1.

increased addition of water to the luminal fluid, the concentrations of these components would have decreased during the non-luteal relative to the luteal phase of the cycle.

The similarities and dissimilarities in the composition of blood serum and oviduct fluid observed in this study support the concept that oviduct fluid is a combination of transudate and secretion of the epithelium (Brackett \& Mastroianni, 1974). The cholesterol and protein concentration gradients which exist from serum to oviduct fluid suggest that these substances in oviduct 
fluid may be transudate from serum. The cholesterol gradient was somewhat less during the luteal than the non-luteal phase, which may indicate that the gradient is influenced by the oestrous cycle.

The higher concentration of phospholipid in oviduct fluid compared with serum may indicate that the oviduct epithelium synthesizes and secretes phospholipids, or has the ability to concentrate phospholipids derived from serum. If the latter, it is likely that the process of concentration of phospholipid from serum to oviduct fluid is selective since the relative amounts of phospholipids contained in oviduct fluid do not mirror that of serum throughout the cycle.

Phospholipids in oviduct fluid may serve as an energy source for spermatozoa since spermatozoa are able to hydrolyse selectively certain phospholipids (Lardy \& Phillips, 1941; Scott \& Dawson, 1968 ) and are also known to utilize fatty acids (Hartree \& Mann, 1959, 1961; Mills \& Scott, 1969).

The phospholipid composition of oviduct fluid near oestrus may function in preparing spermatozoa for fertilization. Phospholipids become associated with spermatozoa incubated in vitro (Evans \& Setchell, 1978; Wang et al., 1981) and the phospholipid composition of spermatozoa is altered for spermatozoa incubated in vivo in the uterus and oviduct (Snider \& Clegg, 1975; Evans et al., 1980). Naturally occurring phospholipids are capable of inducing or inhibiting the acrosome reaction, and lysophospholipids generally promote induction of the acrosome reaction (Meizel, 1978; Fleming \& Yanagimachi, 1981). Almost 50\% of the oviduct fluid phospholipids detected in the present study were lysophospholipids, and concentrations of lysophospholipids peaked around oestrus. Therefore, the phospholipid environment provided by oviduct fluid at oestrus may facilitate sperm capacitation and the acrosome reaction.

Alteration of the cholesterol-phospholipid ratio of sperm membranes may also be involved in the mechanism of sperm capacitation. For rat spermatozoa undergoing capacitation in vitro, this involves a decrease in the cholesterol/phospholipid ratio brought about by the transfer of cholesterol in the membrane to albumin in the medium (Davis et al., 1979). In the present study the cholesterol to protein ratio decreased in oviduct fluid around oestrus, which may indicate an increased ability of oviduct fluid proteins to take up cholesterol from spermatozoa.

In conclusion, the present study has demonstrated that oviduct fluid is rich in phospholipid and that the total production and composition of this lipid is influenced by the oestrous cycle. The lipid composition of oviduct fluid may facilitate the preparation of gametes for fertilization or serve as an energy source for spermatozoa.

Authorized for publication as paper No. 7849 in the journal series of the Pennsylvania Agricultural Experiment Station. Research was supported by USDA grant No. 85-CRCR-1841.

\section{References}

Black, D.L., Duby, R.T. \& Reisen, J. (1963) Apparatus for the continuous collection of sheep oviduct fluid. J. Reprod. Fert. 6, 257-260.

Black, D.L., Crowley, L.V., Duby, R.T. \& Spilman, C.H. (1968) Oviduct secretion in the ewe and the effect of oviduct fluid on oxygen uptake by ram spermatozoa in vitro. J. Reprod. Fert. 15, 127-130.

Brackett, B.G. \& Mastroianni, L. (1974) Composition of oviductal fluid. In The Oviduct and its Functions, pp. 133-160. Eds A. D. Johnson \& C. W. Foley. Academic Press, New York.

Clewe, T.H. \& Mastroianni, L. (1960) A method for continuous volumetric collection of oviduct secretion. $J$. Reprod. Fert. 1, 146-150.

Davis, B.K., Byrne, R. \& Hungund, B. (1979) Studies on the mechanism of capacitation II. Evidence for lipid transfer between plasma membrane of rat sperm and serum albumin during capacitation in vitro. Biochim. Biophys. Acta 558, 257-266.
Edwards, R.G. (1980) The female reproductive tract. In Conception in the Female, pp. 416-524. Academic Press, London.

Elliott, D.S. (1974) Ova and embryo metabolism: functions of the oviduct. In The Oviduct and its Functions, pp. 301-332. Eds A. D. Johnson \& C. W. Foley. Academic Press, New York.

Evans, R.W. \& Setchell, B.P. (1978) Association of exogenous phospholipids with spermatozoa. J. Reprod. Fert. 53, 357-362.

Evans, R.W., Weaver, D.E. \& Clegg, E.D. (1980) Diacyl, alkenyl, and alkyl ether phospholipids in ejaculated, in utero-, and in vitro-incubated porcine spermatozoa. J. Lipid Res. 21, 223-228.

Fleming, A.D. \& Yanagimachi, R. (1981) Effects of various lipids on the acrosome reaction and fertilizing capacity of guinea-pig spermatozoa with special reference to the possible involvement of lysophospholipids in the acrosome reaction. Gamete Res. 4, 253-273. 
Folch, J., Lees, M. \& Sloane-Stanley, G.H. (1957) A simple method for isolation and purification of total lipids from animal tissue. J. biol. Chem. 226, 497.

Hartree, E.F. \& Mann, T. (1959) Plasmalogen in ram semen and its role in sperm metabolism. Biochem. $J$. $71,423-434$.

Hartree, E.F. \& Mann, T. (1961) Phospholipids in ram semen: metabolism of plasmalogen and fatty acids. Biochem. J. 80, $464-476$.

Kavanaugh, J.F. \& Killian, G.J. (1988) Bovine oviductal cannulations. J. Investigative Surgery 1, 201-208.

Killian, G.J. \& Chapman, D.A. (1980) Glycerylphosphorylcholine, sialic acid and protein in epididymal epithelial cells isolated from the rat caput epididymidis by elutriation. Biol. Reprod. 22, 846-850.

Lardy, H.A. \& Phillips, P.H. (1941) Phospholipids as a source of energy for motility of bull spermatozoa. Am. J. Physiol. 134, 542-548.

Lowry, O.H., Rosebrough, N.J., Farr, A.L. \& Randall, R.J. (1951) Protein measurement with the Folin phenol reagent. J. biol. Chem. 193, 265-275.

Mastroianni, L., Jr, Beer, F., Shatt, U. \& Clewe, T.H. (1961) Endocrine regulation of oviduct secretion in the rabbit. Endocrinology 68, 92-100.

McDonald, M.F. \& Bellve, A.R. (1969) Influence of oestrogen and progesterone on flow of fluid from the Fallopian tube in the ovariectomized ewe. $J$. Reprod. Fert. 20, 51-61.

Meizel, S. (1978) The mammalian sperm acrosome reaction: a biochemical approach. In Development in Mammals, Vol. 3, pp. 1-62. Ed. M. H. Johnson. North-Holland Publishing, Amsterdam.

Menezo, Y., Testart, J., Khatchadourian, C. \& Frydman, R. (1984) Human preovulatory follicular fluid: the lipids. Are they the trigger for capacitation? Int. $J$. Fertil. 29, 61-64.
Mills, S.C. \& Scott, T.W. (1969) Metabolism of fatty acids by testicular and ejaculated ram spermatozoa. J. Reprod. Fert. 18, 367-369.

Mukherjee, A.B. \& Lippes, J. (1972) Effect of human follicular and tubal fluids on human, mouse and rat spermatozoa. Can. J. Genet. Cytol. 14, 167-174.

Scott, T.W. \& Dawson, R.M.C. (1968) Metabolism of phospholipids by spermatozoa and seminal plasma. Biochem. J. 108, 457-463.

Sloan, M.H. \& Johnson, A.D. (1974) The influence of a cannula in the rabbit oviduct. J. Reprod. Fert. 33, 149-153.

Snider, D.R. \& Clegg, E.D. (1975) Alteration of phospholipids in porcine spermatozoa during in-vivo uterus and oviduct incubation. J. Anim. Sci. 40, 269-274.

Sutton, R., Nancarrow, C.D., Wallace, A.L.C. \& Rigby, N.W. (1984) Identification of an oestrus-associated glycoprotein in oviducal fluid of the sheep. J. Reprod. Fert. 72, 415. 422

Wang, C.Y., Killian, G.J. \& Chapman, D.A. (1981) Association of ${ }^{14} \mathrm{C}$-phosphatidylcholine with epididymal sperm and its conversion to ${ }^{14} \mathrm{C}$-glycerylphosphorylcholine by sperm and principal cells. Biol. Reprod. 25, 969-976.

Yanagimachi, R. (1969) In-vitro capacitation of hamster spermatozoa by follicular fluid. J. Reprod. Fert. 18 , 275-286.

Zavos, P., Tauber, P.F. \& Schumacher, G.F.B. (1982) The tubular organs of the female genital tract. In Biochemistry of Mammalian Reproduction, pp. 175-202. Eds L. J. D. Zaneveld \& R. T. Chatterton. John Wiley and Sons, New York. 